\title{
PENINGKATAN KAPASITAS DAN EFISIENSI PRODUKSI KERIPIK USUS PEPAYA DI KELOMPOK WANITA TANI SARI REJO III, KECAMATAN TUMPANG, KABUPATEN MALANG
}

\author{
Increasing Capacity and Eficienncy of Papaya Chips Production at Women Farmer Group \\ Sari Rejo III at Tumpang District, Malang Regency \\ Teti Estiasih dan Joni Kusnadi \\ Jurusan Teknologi Hasil Pertanian, Fakultas Teknoloi Pertanian, Universitas Brawijaya Jl. Veteran, \\ Malang \\ Email: teties@yahoo.co.id
}

\begin{abstract}
Papaya is a plant widely found in the village Duwet and almost planted in every home. The papaya is partially processed into typical food that is papaya chips. Problems found in Women Farmer Group Sari Rejo III are the quality of processed product which still have to be improved, and the manual and traditional processing. The drying process on the processing papaya chips is done sun drying that takes 2-3 days during cloudy weather. This condition leads to moldy papaya chips. Imperfect drying causes low product quality of papaya chips that indicated by becomes hard texture. Slicing of papaya is still manually using a household scale chopper that produces not uniform size. Frying of papaya chips has a constraint that temperature is difficult to control. Partners also have difficulties in the packaging of products because of manual process. Program to solve the problems are as follows: (1) increasing efficiency and drying capacity of papaya chips, (2) increasing the efficiency and capacity of papaya chips slicing, (3) improvement of frying papaya chips control, and (4) increasing packaging efficiency. In this program, we have performed mechanical technology transfer for slicing, drying, and frying of papaya chips, and also accuracy and speed of product packaging.
\end{abstract}

Keywords: technology transfer, diversification, papaya chips

\begin{abstract}
ABSTRAK
Pepaya merupakan tanaman yang banyak ditemui di Desa Duwet dan hampir ditanam di setiap rumah warga. Pepaya tersebut sebagian diolah menjadi makanan khas yaitu keripik usus pepaya. Permasalahan yang ditemui mitra KWT Sari Rejo III adalah kualitas produk olahan yang masih harus ditingkatkan dan pengolahan yang masih manual dan tradisional. Proses pengeringan pada pengolahan keripik usus pepaya dilakukan dengan cara penjemuran sehingga memerlukan waktu 2-3 hari dan jika cuaca mendung menyebabkan bahan menjadi berjamur. Pengeringan yang tidak sempurna menyebabkan kualitas produk menjadi rendah akibat keripik usus pepaya menjadi keras atau tidak renyah. Perajangan pada pengolahan keripik usus pepaya masih manual menggunakan alat perajang skala rumah tangga sehingga ukuran tidak seragam dan memakan waktu lama. Penggorengan keripik usus pepaya, stik pepaya dan stik pelas terkendala kontrol suhu yang sulit. Mitra juga mengalami kesulitan dalam pengemasan produk yang masih manual. Pada program ini dilakukan program sebagai berikut (1) peningkatan efisiensi dan kapasitas pengeringan keripik usus pepaya dan diversifikasi teh kulit apel (2) peningkatan efisiensi dan kapasitas perajangan keripik usus pepaya dan keripik apel, (3) peningkatan pengendalian proses penggorengan keripik usus pepaya, stik pepaya, dan stik pelas, (4) peningkatan mutu keripik buah, (5) peningkatan efisiensi pengemasan, dan (6) pendampingan peningkatan mutu dan keamanan produk melalui penerapan GMP dan SOP (standard operating procedure). Dari program IbM ini, telah dilakukan alih teknologi mekanis
\end{abstract}


untuk perajangan, pengeringan, dan penggorengan keripik usus pepaya, stik pepaya, dan stik pelas; peningkatan akurasi dan kecepatan pengemasan produk.

Kata kunci: alih teknologi, diversifikasi, keripik usus pepaya

\section{PENDAHULUAN}

Desa Duwet, Kecamatan Tumpang, Kabupaten Malang, mempunyai produk pangan olahan berbasis potensi wilayah setempat yaitu pepaya dan buah-buahan. Produk olahan Desa Duwet adalah keripik usus pepaya, stik pepaya, stik pelas (pepayatalas), dan keripik buah yang diproduksi oleh KWT (Kelompok Wanita Tani) Sari Rejo III. Produk keripik usus pepaya merupakan produk olahan dari pepaya muda yang dirajang berbentuk stik kemudian dijemur. Stik pepaya yang sudah dijemur kemudian diberi tepung dan bumbu untuk selanjutnya digoreng. Proses produksi keripik usus pepaya masih manual yaitu perajangan dengan cara menggunakan perajang kayu sehingga proses perajangan untuk pepaya muda sebanyak $4 \mathrm{~kg}$ memerlukan waktu 1 jam. Perajangan manual ini menghasilkan produk dengan ukuran yang tidak seragam. Pengeringan irisan pepaya dilakukan dengan penjemuran di bawah sinar matahari. Desa Duwet karena berada di dataran tinggi tidak mempunyai sinar matahari yang terik. Akibatnya proses penjemuran menjadi lama dan ketika musim penghujan, mitra tidak bisa melakukan aktivitas produksi. Penjemuran yang lama juga seringkali mengakibatkan irisan pepaya menjadi berjamur.

Proses pengolahan keripik usus pepaya dapat dilihat pada Gambar 3. Pepaya mengkal diiris tipis-tipis berbentuk stik dan dijemur. Pengirisan ini merupakan tittik kritis pertama (critical point 1, CP-1) karena harus tipis dan seragam untuk mendapatkan keripik usus pepaya yang renyah. Pengirisan masih manual menggunakan alat perajang skala kecil dari kayu sehingga memakan waktu lama. Penjemuran juga merupakan titik kritis (critical point 2, CP2) karena pengeringan tradisional dengan penjemuran memakan waktu 2-3 hari pada cuaca cerah dan lebih lama lagi pada saat cuaca mendung atau hujan. Hal ini juga berdampak terhadap kerenyahan produk. Penjemuran yang lama akibat cuaca mendung/hujan seringkali menyebabkan irisan pepaya menjadi berjamur dan kurang renyah.

Menurut Sagar dan Kumar (2010), pengeringan dengan menggunakan penjemuran dan pengeringan matahari mengakibatkan kualitas produk menjadi rendah dan terkontaminasi. Faktor penting pada proses pengeringan adalah kecepatan transfer panas untuk menurunkan pembentukan crust. Pembentukan crust akibat penjemuran yang tidak terkontrol ini yang menyebabkan produk keripik usus pepaya menjadi tidak renyah. Menurut Chen (2008), pengeringan membentuk mikrostruktur dan mengakibatkan distribusi spasial mikrostruktur yang mempengaruhi densitas dan menentukan tekstur dari produk.

Selanjutnya setelah dijemur, irisan pepaya digoreng setelah terlebih dahulu dilumuri tepung ditambah bumbu. Proses penggorengan merupakan tahapan yang sulit karena jika api terlalu besar, keripik usus pepaya menjadi gosong. Sebaliknya jika api terlalu kecil, keripik usus pepaya menjadi berpuntir, sehingga proses penggorengan ini merupakan titik kritis yang harus dikontrol (critical point 3, CP-3). Menurut Choe dan Min (2007), penggorengan dengan suhu terlalu rendah atau terlalu pendek menyebabkan warna yang pucat dan pati yang belum tergelatinisasi atau tergekatinisasi parsial mengakibatkan tekstur yang tidak renyah dan flavor yang tidak optimum. Sebaliknya, penggorengan yang telalu lama atau suhu terlalu tinggi mengakibatkan warna gelap dan tekstur 
berminyak akibat banyak minyak yang terserap.

Selanjutnya, setelah penggorengan adalah pengatusan minyak menggunakan spinner. Produk selanjutnya dikemas dengan menggunakan manual sealer. Manual sealer yang dimiliki mitra berkualitas rendah sehingga seringkali pengemasan tidak sempurna yang menyebabkan produk mudah melempem. Mitra menginginkan peningkatan kinerja pengemasan dengan menggunakan pengemas kontinyu tipe vertikal sehingga pengemasan lebih akurat dan lebih cepat.

\section{METODE PELAKSANAAN}

Pelaksanaan kegiatan IbM ini ditujukan untuk menyelesaikan permasalahan yang dihadapi oleh mitra KWT Sari Rejo III Desa Duwet, Kecamatan Tumpang, Kabupaten Malang pada proses produksi pangan olahan. Berdasarkan pada permasalahan mitra yang sudah diuraikan, metode pelaksanaannya adalah sebagai berikut:

\section{Peningkatan efisiensi dan kapasitas pengeringan keripik usus pepaya}

Dari hasil diskusi dengan mitra KWT Sari Rejo III yang memperoduksi keripik usus pepaya, kendala yang dihadapi pada proses produksi keripik usus pepaya adalah proses pengeringan yang masih tradisional dengan penjemuran. Dampaknya adalah kualitas keripik yang tidak renyah jika cuaca mendung atau hujan karena pengeringan lama. Dampak lain adalah keripik menjadi berjamur. Alih teknologi pengeringan menggunakan pengering kabinet merupakan solusi untuk mengatasi masalah ini. Penggunaan pengering kabinet dapat dilakukan secara bersama-sama untuk semua produsen keripik anggota KWT Sari Rejo III karena masih bermukim di desa yang sama.

\section{Peningkatan efisiensi dan kapasitas perajangan keripik usus pepaya}

Mitra KWT Sari Rejo III yang memproduksi keripik usus pepaya dan keripik apel mempunyai kendala proses perajangan yang masih manual sehingga memakan waktu lama dan ketebalan irisan yang tidak seragam. Untuk mengatasi hal ini dapat dilakukan alih teknologi mesin perajang dengan kapasitas $100 \mathrm{~kg} / \mathrm{jam}$. Dengan menggunakan mesin ini ukuran ketebalan dan keseragaman irisan pepaya dapat diperbaiki. Selain itu alat ini dapat meningkatkan kecepatan perajangan.

\section{Peningkatan pengendalian proses penggorengan keripik usus pepaya}

Kendala lain yang dihadapi oleh mitra pada proses produksi keripik usus pepaya adalah tahapan akhir proses yaitu proses penggorengan yang tidak terkontrol. Tahapan ini adalah titik kritis karena jika tidak dilakukan dengan baik, proses pengolahan mulai dari bahan baku sampai siap digoreng menjadi sia-sia. Masalah utama yang dihadapi terutama pada pengolahan keripik usus pepaya adalah pengendalian proses penggorengan yang sulit dilakukan. Seringkali produk menjadi gosong akibat suhu penggorengan tinggi atau kurang renyah akibat penggorengan terlalu lama pada suhu rendah. Khusus untuk keripik usus pepaya, penggorengan suhu rendah menyebabkan produk berpuntir sehingga tidak menarik. Alih teknologi penggorengan mekanis menggunakan sistem deep frying dengan kontrol suhu menjadi penting dilakukan. Alat mekanis yang penting dimiliki mitra adalah deep fryer dengan sistem kontrol suhu.

\section{Peningkatan efisiensi pengemasan}

Dari hasil diskusi dengan mitra KWT Sari Rejo III, mitra mengalami kendala dalam proses pengemasan yang masih menggunakan sealer manual. Penggunaan alat tersebut seringkali menyebabkan kemasan tidak bisa tertutup rapat dan kualitas pengemasan yang buruk. Mitra menginginkan mesin pengemas yang lebih baik yaitu mesin pengemas kontinyu tipe vertikal. 


\section{HASIL DAN PEMBAHASAN}

\section{Peningkatan efisiensi dan kapasitas pengeringan keripik usus pepaya}

Dari hasil diskusi dengan mitra KWT Sari Rejo III yang memperoduksi keripik usus pepaya, kendala yang dihadapi pada proses produksi keripik usus pepaya adalah proses pengeringan yang masih tradisional dengan penjemuran. Dampaknya adalah kualitas keripik yang tidak renyah jika cuaca mendung atau hujan karena pengeringan lama. Dampak lain adalah keripik menjadi berjamur, yang mengakibatkan proses produksi akhirnya menjadi gagal.

Alih teknologi pengeringan menggunakan pengering kabinet merupakan solusi untuk mengatasi masalah ini. Penggunaan pengering kabinet dapat dilakukan secara bersama-sama untuk semua produsen keripik dan beras/menir jagung anggota KWT Sari Rejo III karena masih bermukim di desa yang sama. Pengering kabinet dapat dilihat pada Gambar 1. Pengering kabinet tersebut menggunakan bahan bakar gas elpiji dnegan suhu terkontrol sehingga proses pengeringan menjadi terkendali. Kapasitas pengering kabinet 6 rak dapat memuat $30 \mathrm{~kg}$ rajangan pepaya per batch. Sistem pengering kabinet yang dilengkapi dnegan blower menyebabkan proses pengeringan berjalan cepat karena adanya hembusan untuk sirkulasi udara panas.

Hasil pengeringan rajangan buah pepaya dapat dilihat pada Gambar 2 . Rajangan buah pepaya kering mempunyai bentuk yang tipis mirip kertas dan panjang. Pada proses pembuatan keripik usus pepaya, rajangan pepaya kering digoreng dengan menggunakan penyalut tepung. Proses penyalutan dilakukan dengan mencelupkan rajangan pepaya kering ke dalam adonan cair (batter) kemudian dilanjutkan dengan pencelupan pada tepung kering. Selanjutnya dilakukan proses penggorengan hingga kering. Rajangan pepaya hasil pengeringan yang tidak kering menyebabkan irisan pepaya menjadi berjamur.

Alih teknologi pengeringan kabinet dapat mempersingkat proses pengolahan keripik dari 2-3 hari penjemuran menjadi 3 jam untuk satu batch produksi. Dengan kapasitas 6 rak atau $30 \mathrm{~kg}$ bahan per batch, maka kapasitas produksi keripik usus pepaya mitra dapat ditingkatkan dari $10 \mathrm{~kg}$ per hari menjadi $30 \mathrm{~kg}$ per hari.
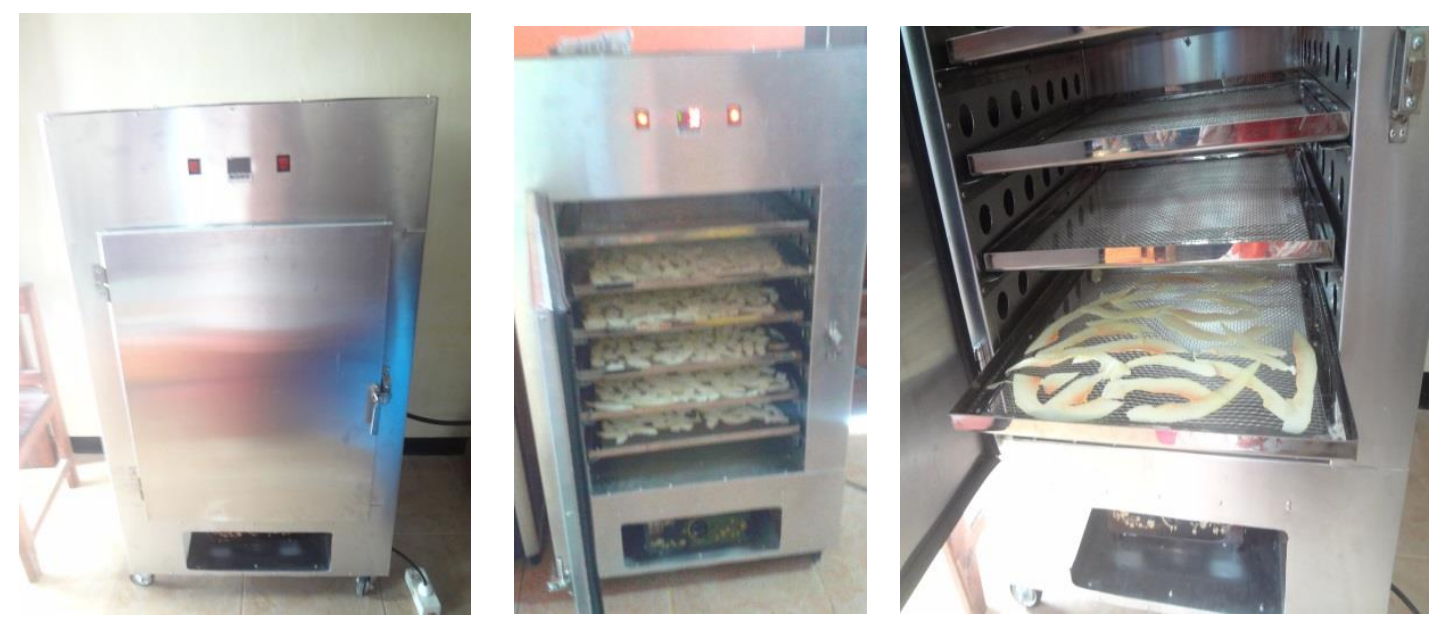

Gambar 1. Pengering kabinet 

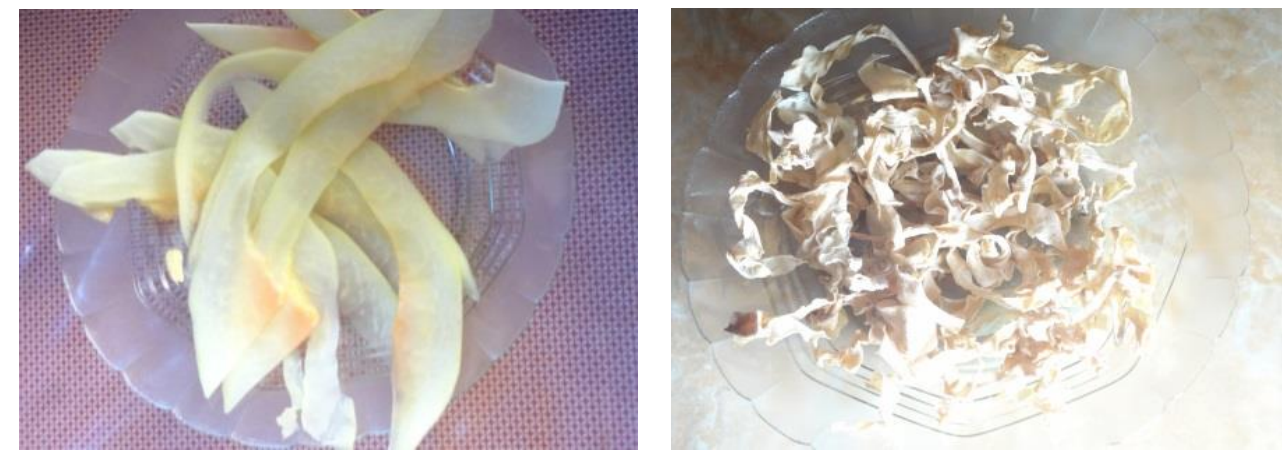

Gambar 2. Rajangan pepaya dan rajangan pepaya yang sudah dikeringkan

\section{Peningkatan efisiensi dan kapasitas perajangan keripik usus pepaya}

Mitra KWT Sari Rejo III yang memproduksi keripik usus pepaya mempunyai kendala proses perajangan yang masih manual sehingga memakan waktu lama dan ketebalan irisan yang tidak seragam. Untuk mengatasi hal ini dapat dilakukan alih teknologi mesin perajang dengan kapasitas $100 \mathrm{~kg} / \mathrm{jam}$. Dengan menggunakan mesin ini ukuran ketebalan dan keseragaman irisan pepaya dapat diperbaiki. Selain itu alat ini dapat meningkatkan kecepatan perajangan.

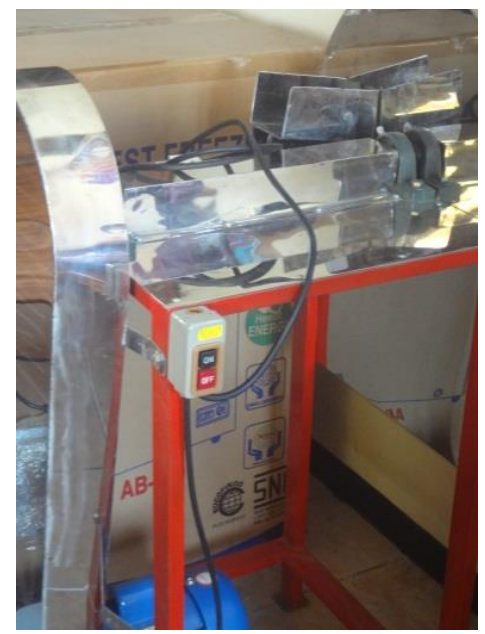

Gambar 3. Perajang mekanis

\section{Peningkatan pengendalian proses penggorengan keripik usus pepaya}

Kendala lain yang dihadapi mitra pada proses produksi keripik usus pepaya, stik pepaya, dan stik pelas adalah tahapan akhir proses yaitu proses penggorengan yang tidak terkontrol. Tahapan ini adalah titik kritis karena jika tidak dilakukan dengan baik, proses pengolahan mulai dari bahan baku sampai siap digoreng menjadi sia-sia. Masalah utama yang dihadapi terutama pada pengolahan keripik usus pepaya adalah pengendalian proses penggorengan yang sulit dilakukan. Seringkali produk menjadi gosong akibat suhu penggorengan tinggi atau kurang renyah akibat penggorengan terlalu lama pada suhu rendah. Khusus untuk keripik usus pepaya, penggorengan suhu rendah menyebabkan produk berpuntir sehingga tidak menarik.Alih teknologi penggorengan mekanis menggunakan sistem deep frying. Alat mekanis yang penting dimiliki mitra adalah deep fryer.

Permasalahan pada proses penggorengan adalah suhu penggorengan yang tidak merata akibat minyak di bagian atas bahan kurang merendam. Dengan mengguankan deep fryer ini, proses penggorengan merendam semua bahan dan proses pengangkatan menajdi lebih mudah. Sistem penggorengan yang tertutup ini menyebabkan proses transfer panas menjadi lebih efisien karena panas yang mengalami konveksi ke lingkungan menjadi terbatas. Dengan kondisi ini, proses penggorengan bisa lebih efisien dan cepat. Penggunaan wadah untuk penggorengan menyebabkan proses pengangkatan bahan yang digoreng menjadi lebih cepat. 

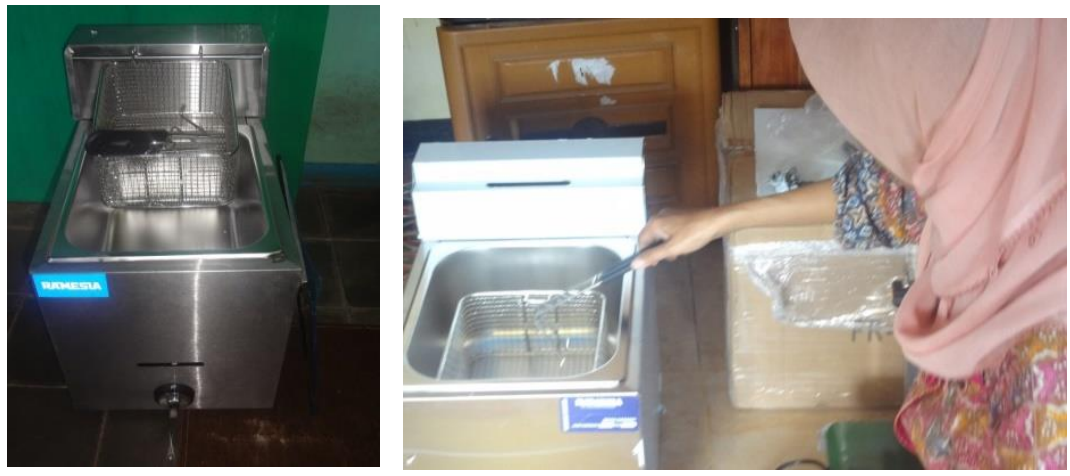

Gambar 4. Deep fryer

\section{Peningkatan efisiensi pengemasan}
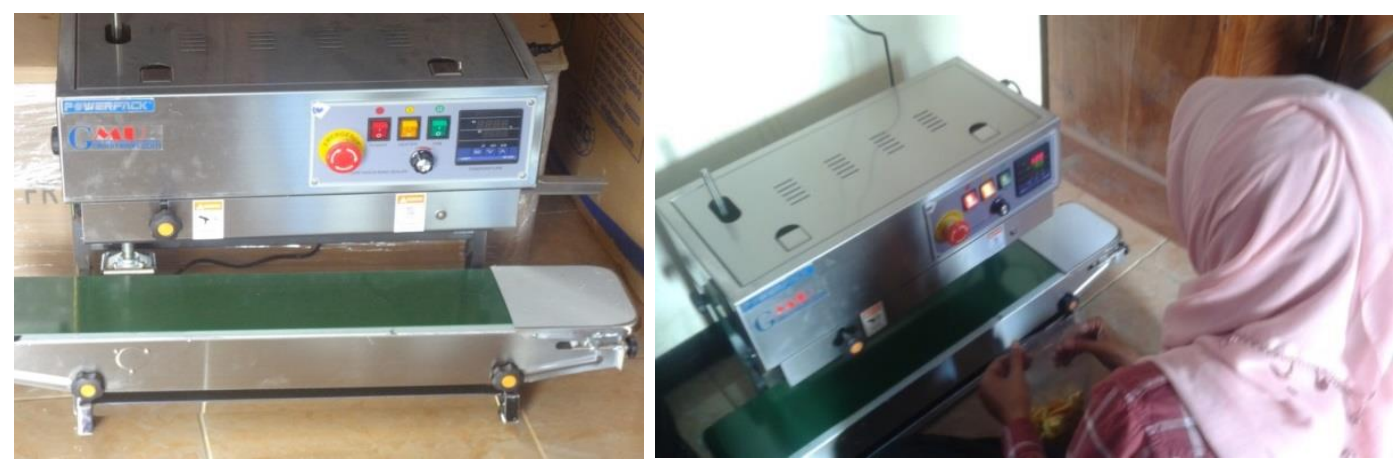

Gambar 5. Mesin pengemas kontinyu tipe vertikal

Mitra KWT Sari Rejo III, mitra mengalami kendala dalam proses pengemasan yang masih menggunakan sealer manual. Penggunaan alat tersebut seringkali menyebabkan kemasan tidak bisa tertutup rapat dan kualitas pengemasan yang buruk. Mitra menginginkan mesin pengemas yang lebih baik yaitu mesin pengemas kontinyu tipe vertikal seperti dapat dilihat pada Gambar 5.

Peningkatan kecepatan dan akurasi pengemasan keripik usus pepaya, stik pelas, dan stik pepaya dapat dilakukan dengan menggunakan mesin pengemas tersebut karena kecepatan pengemasan $5 \mathrm{~kg}$ per loading. Keunggulan mesin ini adalah suhu yang bisa diatur sehingga mitra KWT Sari Rejo III dapat menggunakan kemasan tebal. Selain itu, proses pengemasan lebih sempurna dan rapat jika dibandingkan penggunaan hand sealer yang selama ini dilakukan mitra.

Peningkatan efisiensi proses dan peluang peningkatan kapasitas produksi akibat proses mekanisasi mesin pengering dan perajang untuk produksi keripik usus pepaya dapat dilihat pada Tabel 1. Mitra mempunyai peluang meningkatkan kapasitas produksinya menjadi 5 kali lipat.

Tabel 1 . Perbandingan efisiensi produksi sebelum dan setelah mekanisasi melalui Program IbM dan peningkatan kapasitas produksi

\begin{tabular}{llcccc}
\hline No. & Tahapan & $\begin{array}{c}\text { Jumlah } \\
\text { pepaya }\end{array}$ & $\begin{array}{c}\text { Lama } \\
\text { proses awal }\end{array}$ & $\begin{array}{c}\text { Peningkatan } \\
\text { kapasitas pepaya }\end{array}$ & $\begin{array}{c}\text { Lama proses } \\
\text { setelah program }\end{array}$ \\
\hline 1. & Perajangan & $10 \mathrm{~kg}$ & 1 jam & $50 \mathrm{~kg}$ & 1 jam \\
2. & Pengeringan & $10 \mathrm{~kg}$ & $2-3$ hari & $30 \mathrm{~kg}$ & 3 jam \\
3. & Penggorengan & $10 \mathrm{~kg}$ & 2 jam & $10 \mathrm{~kg}$ & 2 jam \\
4. & Pengemasan & $10 \mathrm{~kg}$ & 1 jam & $50 \mathrm{~kg}$ & 1 jam \\
\hline
\end{tabular}




\section{KESIMPULAN}

Dari hasil sementara pelaksanaan program $\mathrm{IbM}$ ini dapat disimpulkan bahwa Program IbM melalui alih teknologi mekanis pengeringan telah meningkatkan kapasitas dan pengendalian proses pengeringan keripik usus pepaya. Kapasitas perajangan meningkat dengan adanya mesin perajang mekanis. Penggunaan mesin pengemas vertikal sistem kontinyu telah meningkatkan efisiensi dan kualitas pengemasan produk olahan pangan KWT Sari Rejo III.

\section{UCAPAN TERIMA KASIH}

Ucapan terima kasih disampaikan pada Direktorat Penelitian dan Pengabdian kepada Masyarakat, Direktorat Jenderal Pendidikan Tinggi, Kementerian Riset, Teknologi dan Pendidikan Tinggi atas pendanaan kegiatan melalui skim Iptek bagi Masyarakat (IbM) Tahun 2016 dengan Nomor Penugasan: 019/SP2H/ PPM/
DRPM/II/ 2016 tanggal 18 Februari 2016, serta Lembaga Penelitian dan Pengabdian kepada Masyarakat (LPPM) Universitas Brawijaya.

\section{DAFTAR PUSTAKA}

Chen, X. D. 2008. Food drying fundamentals. Dalam Chen, X.D. dan A.S. Mujumdar (eds). Drying Technologies in Food Processing. Blackwell Publishing, Singapore.

Choe, E. and D.B. Min. 2007. Chemistry of Deep-Fat Frying Oils. Journal of Food Science 72(5): R77-R86.

Sagar, V.R. and Kumar, S.P. 2010. Recent Advances in Drying and Dehydration of Fruits and Vegetables: A Review. J. Food Sci. Technol. 47(1):15-26.

Sahin, S. and S.G. Sumnu. 2009. Introduction. Dalam S. Sahin dan S.G. Sumnu (eds.). Advances in DeepFat Frying of Foods. CRC Press, Boca Raton. 